\title{
CHINESE STATE-OWNED ENTERPRISES AND THE CONCEPT OF UNDERTAKING UNDER EU COMPETITION LAW
}

\section{Václav Šmejkal *}

\begin{abstract}
Chinese State-owned enterprises (SOEs) test the ability of the existing EU legal framework for the protection of economic competition to regulate entities originating from the systemically different socialist market economy of today's China. The question left unanswered so far is whether or not is the EU competition law sufficiently neutral and flexible to be universally applicable and able to encompass corporate structures guided and managed differently from its underlying assumptions. Thus, one of the main theses of the following analysis is that the key concepts of the undertaking and of the single economic unit under EU competition law do not correspond to the reality of Chinese SOEs. They cause difficulties of interpretation and, in particular, of application on Chinese SOEs and even could weaken the EU competition law ability to protect competition by standard procedures. To solve that puzzle for the EU competition law, the following text proposes that the Commission and the CJEU should opt for a different interpretation of the concept of undertaking / single economic unit for the purposes of SOEs ex-ante merger scrutiny on one hand, and their internal practices' ex-post investigation and sanctions on the other.
\end{abstract}

KEYWORDS: Chinese state-owned enterprises, EU competition law, undertaking, single economic unit, merger control

\footnotetext{
Václav Šmejkal is Associete Professor of European Law at Charles University in Prague, Senior Lecturer at Law and Economics' Department of ŠKODA AUTO University in Mladá Boleslav and Visiting Scholar at the Faculty of Ecoomics and Business, University of Zagreb; smejkalv@prf.cuni.cz This article is based on his contribution to the Czech-Chinese Legal Forum held in Prague on October 23, 2019.
} 


\section{INTRODUCTION}

The growth and global expansion of Chinese economy is undoubtedly one of the defining features of contemporary world. Europe that used to export its political, economic and cultural influence on the rest of the world over the past three centuries now gets with China's into a situation in which the roles of the center and the periphery have reversed and where the "weaker" one is the former center. Symptomatically, this European nausea from new global order has recently emerged in the media response to the negative attitude of the European Commission, which in February 2019 thwarted the mega fusion in the European rail business between Siemens and Alstom ${ }^{1}$. In the headlines, China has become an "economic threat" in the face of which the EU plays „the fool" 3 because it does not allow its companies to "compete with global giants"4 successfully. But it was only one of the more visible manifestations of developments that have been going on for some time and have led to a lot of discussion on how the EU should approach an ambiguous relationship with a politically, socially and culturally diverse partner which became a global generator of production, investments and high technologies.

An important part of the discussions is the EU's approach to the drivers of China's economic expansion - undertakings, first of all, to Chinese stateowned enterprises (SOEs) as the entities owned and therefore influenced by the Chinese government and the Chinese Communist Party (CCP). It is common ground in European literature to point out that these enterprises are not subject to usual (by Western standards) market rules and risks. China provides its companies with political, financial and information support, rent-free use of land and discounted resources such as electricity and water, allowing them exemptions from competition law, protecting them from bankruptcy even in case of over-indebtedness 5 . The coordinating role of government bodies such

1 European Commission, Press release Database, Mergers: Commission prohibits Siemens' proposed acquisition of Alstom. Brussels, 6 February 2019 https://europa.eu/rapid/press-release_IP-19-881_en.htm Last accessed on 01/10/2010.

2 See for instance: Toplensky, R., Brunsden, J., EU competition chief urges higher defences against China threat. The Financial Times, January 16, 2019.

3 See for instance: Ploquin, J.-C., Chine, comment les Européens veulent en finir avec le jeu de dupes. La Croix, 26 Mars 2019.

4 See for instance: Lauer, S. European companies can't compete against global giants. The Guardian, May 17, 2019.

5 García-Herrero, A., Jianwei X., How to handle state-owned enterprises in EU-China investment talks. Bruegel Policy Contribution Issue n. 18, June 2017, p. 8-10; O’Connor, S., SOE Megamergers Signal New Direction in China's Economic Policy. US-China Economic and Security Review Commission, Staff Research Report, May 24, 2019, p. 5; Pelkmans, J., „China's 
as the Assets Supervision and Administration Commission of the State Council (SASAC) ${ }^{6}$ on the one hand, and the presence of party organizations and $\mathrm{CCP}$ members at the positions of CEOs and Board members of $\mathrm{SOEs}^{7}$, on the other, cast doubts about the structural and operational independence of these enterprises from the Chinese State and its policy ${ }^{8}$. As a result, the Chinese SOEs pose a challenge for the EU not only in economic terms, but also on two other levels - legal and political.

On a legal level, the Chinese SOEs test the ability of the existing EU legal framework for the protection of economic competition to regulate entities originating from the systemically different socialist market economy of today's China. The question left unanswered so far is whether or not is the EU competition law sufficiently neutral and flexible to be universally applicable and able to encompass corporate structures guided and managed differently from its underlying assumptions. Thus, one of the main theses of the following analysis is that the key concepts of undertaking and of single economic unit under EU competition law do not correspond to the reality of Chinese SOEs. They cause difficulties of interpretation and, in particular, of application on Chinese SOEs and even could weaken the EU competition law ability to protect competition by standard procedures. The bulk of the text will therefore be devoted to this issue ${ }^{9}$.

Socialist Market Economy“: A systemic Trade Issue. Intereconomics n. 2018/5 ZBW-Leibniz Information Centre for Economics, p. 270-271.

6 The State-owned Assets Supervision and Administration Commission of the State Council (SASAC) is an ad-hoc ministerial-level organization directly subordinated to the State Council. The Party Committee of SASAC performs the responsibilities mandated by the Central Committee of the Chinese Communist Party. Information available from: http://en.sasac.gov. $\mathrm{cn} /$ Last accessed on 01/10/2010.

7 According to recent data as many as $80 \%$ of SOEs' CEOs are party members. As members of CCP "nomenclature" they rotate among different SOEs' managerial positions. See in Briguet, J., The State's Invisible Hand: Chines SOEs Facing EU Antitrust Law. Journal of World Trade 52 No. 5 (2018), p. 849-850.

8 The European Commission itself produced in the end of 2017 a 466-pages long (!) Staff Working Document on Significant Distortions in the Economy of The People's Republic of China for the Purposes of Trade Defence Investigations. Brussels, 20.12.2017 SWD(2017) 483 final/2 in which a chapter is dedicated to critical assessment of SOEs situation. The Commission concluded there (see p. 108) that the Chinese Government and Communist Party had not shied away from exercising the powers available over SOEs and that their current tendency was to put off market-oriented reforms.

9 This issue is discussed with growing intensity in Western literature of the last decade. Examples studied also for the purpose of the present study include: Petit, N., Chinese State Capitalism and Western Antirust Policy. www.ssrn.com/abstract'2798162 21/06/2016 last accessed on 01/10/2010.; James, T. A., Morse, H. M., Regulatory Hurdles facing Mergers with Chinese 
On a political level, there is a growing fear that Chinese firms could win the battle to control global markets, even worse, that they could dominate strategic industrial capacities, technologies and essential infrastructure in the EU. ${ }^{10}$ This logically worries political and industrial circles of the EU, which are now debating what instruments of defense would be efficient and acceptable. The first outcome of this debate at the EU level is the Coordination Regulation 2019/452 on the control of foreign direct investments adopted in April 2019. It encourages EU Member States to establish national control mechanisms, to share information and views on foreign investments that could try with foreign-backing, and often in services of their countries of origin, to acquire strategic assets in the EU. In the near future a reform of the Regulation 139/2004 on the control of concentrations between undertakings (EU Merger Control Regulation - EUMR) could also follow and make it easier, on the one hand, to include risks posed by Chinese SOEs into notified mergers' assessment and, on the other, to introduce certain leniency towards "European champions" to enable them to compete with Chinese competitors ${ }^{11}$. This political aspect of the problem will not be completely avoided in the following text, even if it will be paid attention only as to a possible collateral solution to the problems that the EU has to face in current global economic and geopolitical competition.

State-Owned Enterprises in the United States and the European Union. China Antitrust Journal, vol. 1 Issue 1, Summer 2017; Fountoukakos, K., Puech-Baron, C. China/EU: The gradual evolution of the EU Commission's merger control decisional practice towards SOEs amidst an increasingly protectionist world. Concurrences - Revue des droits de la concurrence. International. n. 4/2017; De Kok, J., Chinese SOEs under EU Competition Law. World Competition 40, No. 4(2017); Briguet, J., The State 's Invisible Hand: Chines SOEs Facing EU Antitrust Law. Journal of World Trade, 52 No. 5 (2018); Svetlicinii, A., The Acquisition of the Chinese State-Owned Enterprises under the EU Merger Control Regime: Time for Reflection? Revue Lamy de la concurrence, N. 67 Décembre 2017; Svetlicinii, A., The Acquisition of the Chinese State-Owned Enterprises under the National Merger Control of the EU Member States: Searching for a Coherent Approach. Market and Competition Law Review, Vol. II, No. 1. April 2018;

10 See for instance: Devonshire-Ellis, C., While the EU Frets about Chinese Investment in Infrastructure, the US Quietly Rearms it. Silk Road Briefing, March 14, 2019, available from: https://www.silkroadbriefing.com/news/2019/03/14/eu-frets-chinese-investment-infrastructure-united-states-quietly-rearms/ Last accessed on 01/10/2010.

11 See for instance: Toplensky, R., Brunsden, J., France calls for biggest shake-up of EU merger rules in 30 years. The Financial Times, February 12, 2019. Crucial political dimension of the most visible reform proposals is proved by an idea from the Franco-German Manifesto of February 2019, that Commission's merger decisions should be reviewed by the Council of the EU, i.e. that the existing independent judicial procedure should be politicized. See A Franco-German Manifesto for a European industrial policy fit for the 21st Century. Feb 19, 2019 https://www.bmwi.de/Redaktion/DE/Downloads/F/franco-german-manifesto-for-a-european-industrial-policy.pdf\%3F__blob\%3DpublicationFile\%26v\%3D2 Last accessed on 01/10/2010. 
The following analysis, therefore, focuses on competition law issues and aims to identify as precisely as possible the problems that EU competition law has to address if it wants to regulate the operation of Chinese SOEs in the EU Single Market and more broadly in the European Economic Area (EU/EEA) so that the open and undistorted competition is maintained there. As a contribution to the ongoing discussion, it will also try to outline and argue potential solution to these problems.

\section{CHINESE SOES AND EU MERGER RULES - THE ISSUE OF „COMMUNITY DIMENSION““}

State-owned enterprises that are vehicles to pursue the Chinese government or, in reality, Chinese Communist Party policies seem to be entities of different nature than those that the EU competition law, founded on values of individualistic, liberalized market-economies, is supposed to regulate. Such discrepancy between EU competition law fundaments and Chinese SOEs' basic characteristics causes practical problems at different levels when coping with real competition cases. The most visible and also the most discussed of these problems is the question of which entities (and their turnover) should be considered when a Chinese SOE takes part in a merger or acquisition that involves an EU-based company or has an impact on the EU market.

\subsection{THE ISSUE OF EUMR'S APPLICABILITY}

The EU Merger Regulation (EUMR) applies (which means that the Commission has the power of control) to all concentrations with a so-called "Community dimension". This dimension is specified in Art 1 EUMR based on a certain level of either the aggregate worldwide and the aggregate EU-wide turnover of undertakings concerned ${ }^{12}$ or their turnover (or at least two of them) in each of at least three Member States of the EU etc. ${ }^{13}$ The exact criteria of

\footnotetext{
12 The turnover in the European Economic Area (EEA) in practice.

13 The Commission explains the criteria laid down in Art 1 of EUMR as follows: There are two alternative ways to reach turnover thresholds for EU dimension. The first alternative requires: (i) a combined worldwide turnover of all the merging firms over $€ 5000$ million, and (ii) an EU-wide turnover for each of at least two of the firms over $€ 250$ million. The second alternative requires: (i) a worldwide turnover of all the merging firms over $€ 2500$ million, and (ii) a combined turnover of all the merging firms over $€ 100$ million in each of at least three Member States, (iii) a turnover of over $€ 25$ million for each of at least two of the firms in each of the three Member States included under ii, and (iv) EU-wide turnover of each of at least two firms of more than $€ 100$ million.In both alternatives, an EU dimension is not met if each of
} 
this jurisdictional threshold and the specific calculation of their fulfillment are for the moment less important than an answer to the question of what shall be the delimitation of the undertaking and its turnover in a merger case involving Chinese SOE(s). According to the paras 192-194 of the Commission's Jurisdictional Notice under the EUMR ${ }^{14}$, that deal with the issue of "Allocation of turnover for State-owned undertakings", the existence of "an independent power of decision" determinates whether a single undertaking is involved or rather a whole group of them - if they make up together an economic unit subjected to unified control.

The Commission's Jurisdictional Notice specifies in paras 193-194 what has been briefly outlined already in the previous chapter: Member States (or their public bodies) are not considered as undertakings simply because they have interests in other undertakings, as the decisive criterion consists in the capacity to take decisions concerning business strategy, plan, budget, composition of management, etc. of a company at issue. If the State and its representatives can take or substantively influence those decisions, then the company is not independent and cannot be, for the turnover calculation purposes, considered as a separate entity. Only when, on the contrary, a State-owned company has the real autonomy of decision and is not subject to any coordination with other State-controlled holdings, it should be treated as an independent undertaking and the turnover of other State-owned companies should not be taken in the account.

To sum it up: in each merger involving a Chinese SOE, the Commission has to cope with the question of whether it is just the turnover of this specific SOE (plus its subsidiaries and branches) that should be taken into calculation, or rather the turnover of all Chinese SOEs under the supervision of the same Chinese state authority - specific ministry, central SASAC, local SASAC, etc., or even of all Chinese SOEs altogether as they are all supervised by the CCP which decides over their general strategy, over appointment or removal of their key managers etc. Consequences are obvious: in one extreme, the Commission would rarely have a jurisdiction to control mergers involving a Chinese SOE that intends to enter the EU market for the first time, however in the opposite one, the Commission would have jurisdiction to review all the mergers involving any of Chinese SOEs as the aggregate turnover of all Chinese SOEs inevitably overcomes the threshold of "Community dimension".

the firms archives more than two thirds of its EU-wide turnover within one and the same Member State. See: https://ec.europa.eu/competition/mergers/procedures_en.html Last accessed on 01/10/2010.

14 Commission Consolidated Jurisdictional Notice under Council Regulation 139/2004 on the control of concentrations between undertakings (2008/C 95/01). 
In the only decision so far, in which the Commission tried to be specific about an independent or dependent status of a Chinese SOE (concentration that consisted in acquisition of joint control by Electricité de France - EDF and by China General Nuclear Power Corporation - CGN over NNB group of companies active in the energy sector $)^{15}$ the Commission based its reasoning on the analysis of the Chinese law on the State-Owned Assets of Enterprises of 2008, and of the document called Interim Measures for the Supervision and Administration of Investments by Central Enterprises of 2003, that entrust the central SASAC with the capacity to:

- Appoint and remove top managers of SOEs, conducts their annual and office term assessments, decides of their rewards and punishments;

- Review the annual investments plan of SOEs, implements administration of any investment activity that goes beyond the annual investment plan, supervise and administrate the investment activities of SOEs;

- Enjoy the return on assets, participates in major decision making, select managers and other contributors' rights;

- Exercise the power to influence coordination between companies active in the energy industry, even to impose such coordination.

Due to such possibilities of influence and control wielded by SASAC, the Commission, contrary to the assertion of merging parties and despite recognizing the absence of interlocking directorship between CGN and other SOEs, concluded that the turnover of all companies controlled by Central SASAC that are active in the energy industry should therefore be aggregated... in the case at hand.

Even though such an outcome could have been expected, the way taken by the Commission to come to it, was quite critically received by many commentators ${ }^{16}$. It is obvious also from the above- provided summary, that the Commission satisfied itself with the analysis of formal legal documents and with the fact of possibility or capacity that they give to Central SASAC to control and coordinate. One can say that the Commission ascertained just the necessary minimum to establish its jurisdiction and did not try to go deeper into the analysis of the whole "matrix" of ties, channels of influence, instances of possible decision-taking that were relevant for the (in)dependence of CGN. This simplification of the task was taken even further by the fact that a mere possibility (the fact that SASAC can do something) was considered enough. On one hand, it is fully justified by the fact that in merger cases the plausible future is

Case M.7850 - EDF/CGN/NNB Group of companies, 10/03/2016.

16 For instance Briguet, J. op. cit. note 9, or Fountoukakos, K, Puech-Baron, C., op. cit. note 9. 
forecasted and thus no one can exclude that an existing legal possibility will be converted into reality (not mentioning the real difficulty for the Commission to assess who wields the formal and who the real power in this or that decision of a Chinese $\mathrm{SOE}^{17}$ ). On the other hand, however, such a possibilistic approach easily leads to the acceptance of "a worst-case scenario" as to an easy way out in all similar cases, due to which the "Community dimension" of a merger would be established without any deeper analysis of what happens in reality and without really calculating any turnover at all.

\subsection{THE WORST-CASE SCENARIO AND ITS CONSEQUENCES}

That is in fact what happens when the Commission has to decide on mergers involving Chinese SOEs. A worst-case scenario is very often used to establish the Community dimension and the Commission's jurisdiction to control the concentration. This approach, dully noticed by many commentators ${ }^{18}$, has obvious consequences. From an analytic or academic point of view we still lack the decision in which the full review of a Chinese SOE situation was carried out and the companies and turnovers included into one single economic unit were specified and calculated. The best what the theory can say is that "it is not possible to make a clear conclusion on the Commission's view on the appropriate size of the economic unit" in cases involving Chinese SOEs. ${ }^{19}$ It can be at least hoped that as the Commission has not so far "narrowed down" its margin of maneuvers by any trendsetting precedent that it would, after the necessary accumulation of know-how and experience, positively surprise in the future. There is however, at least for the time being, a prevailing uncertainty as to what could happen in practice, what companies should do and expect.

First of all, companies are pushed to notify all planned concentrations with Chinese SOEs as under the worst-case scenario they can expect that the Commission will decide in favor of its jurisdiction. This would surely give the

17 The recent example of situation that is difficult to assess is the so-called ChemChina-Sinochem „stealth merger“. World media and analysts only speculate whether the world largest chemical group has been already created in fact (by appointment of a single director) even if it has not been formally announced and it is still publicly denounced by Chinese authorities. If personal ties prevail over formal structures of decision making and management, it is very difficult to enforce law whose applicability depends on the fulfillment of number of standardized conditions. Pucci, J. ChemChina-Sinochem: The New Mega-Company. Agri Business Global, March 19, 2019, available at: https://www.agribusinessglobal.com/markets/ asia/chemchina-sinochem-the-new-mega-company/ Last accessed on 01/10/2010.

18 See for instance the overview of Commission's decision making provided by Svetlicinii, A., op. cit. note 9, or De Kok, J., op. cit. note 9.

19 De Kok, J., op. cit. note 9, p. 604. 
Commission the tool to control more closely the Chinese penetration of the EU market, but would also, at the same time, require the allocation of certain Commission's resources to issuance of decisions that would only state an evident harmlessness of many notified concentrations as to their impact on the EU Single Market competition. Secondly, the worst-case scenario assumption could be used as an argument during the assessment of intra-EU mergers. If there is now a political interest to support creation of European industrial champions, the mere fact that Chinese SOEs are always "big enough" on the world and EU markets and that there is the possibility that they would all follow an expansive strategy centrally orchestrated by Chinese authorities, could hardly not to be stressed by their European competitors in order to secure the Commission's clearance of their own proposed mergers. If the current proposals of the EUMR amendments call for a.o. taking more into account the long-term outlook ${ }^{20}$, one can always argue that there is a huge Chinese single economic unit if not yet present in the $\mathrm{EU}$, then surely at the horizon, and in a long-term perspective it poses a strong competitive pressure on all its EU-based rivals.

The most important and puzzling is however the third consequence. If there is a huge single economic unit encompassing several, many or (at least in theory) all Chinese SOEs then the EU competition law has no application to the internal relations and transformations inside such a unit. Who cannot compete independently is not considered a separate undertaking and, therefore, is not supposed to rival with other entities that makes part of the same economic unit because they are all subjected to the same supervision and guidance. This is the obvious consequence of the EU competition law definitions of undertaking and single economic unit on one hand, and of the embracing of several or many of Chinese SOEs as dependent entities into one and the same single economic unit on the other.

The Commission thus would not have jurisdiction if two or more Chinese SOEs, parts of the same single economic unit, decide to combine, and would not have even the power to control the same moves by their EU-based subsidiaries and branches (as they would, due to a centralized control, belong to the same single economic unit). Such assumption sounds a bit like a doomsday one, as the Commission would have not tool to prevent the dominance of Chinese SEOs merged between themselves on the EU/EEA markets. This is however the inevitable follow-up of the worst-case scenario that is routinely applied by the Commission to the assessment of Chinese SOEs status and

20 Modernising EU Competition Policy, a manifesto issued by Bundesministerium fur Wirtschaft und Energie (GER), Ministere de l'économie et finance (FRA), Ministerstwo Przedsiebiordzosci i Technologii (POL), July 4, 201, available at : https:/www.bmwi.de/Redaktion/ DE/Downloads/M-O/modernising-eu-competition-policy.pdf?__blob=publicationFile \&v=4 Last accessed on 01/10/2010. 
can hardly be rejected if the same single economic unit does not acquire an EU-based company but merely changes its internal structure. It is therefore comforting that the Commission's case-by-case approach leaves so far opened the door for a detailed assessment in cases when a summary decision under the worst-case scenario would lead to an outcome openly detrimental to fair and undistorted competition.

\section{CHINESE SOES AND EU MERGER RULES - THE ISSUE OF „APPRAISAL OF CONCENTRATIONS““}

Establishment of EU jurisdiction over a concentration is only the first step that does not predict in any way that such a concentration would significantly impede competition on the EU Single Market. In the last decade, 2009-2019, the Commission controlled more than 3000 concentrations and stopped only 9 of them $^{21}$. Large companies could also have merged if the affected EU markets remained open and competitive which sometimes had to be achieved though imposed commitments that alleviated Commission's concerns.

\subsection{NO PROHIBITIONS ON COMPETITION GROUND}

No concentration involving Chinese SOEs has been prohibited by a Commission's decision up to now, even the aforementioned EDF/CGN/NNB Group of companies merger was cleared without hindrance because the Commission concluded that "competition in the wholesale supply of electricity in the UK will not be hindered by the transaction given the moderate share of EDF, the very limited market shares of CGN in this market and the presence of other competitions." 22

In one case in 2017, when a giant Chinese SOE ChemChina acquired Syngenta, a Swiss-based leading pesticide supplier worldwide, the Commission imposed commitments in order to remedy on the competition concerns. ChemChina, considered by the Commission under the worst-case scenario, was regarded as one economic entity with other companies owned by the Chinese Central Government, still its purchase of Syngenta was found "compatible with the

\footnotetext{
${ }^{21}$ See for details in: European Political Strategy Center (the European Commission in-house think tank): EU Industrial Policy after Siemens-Alstom. Finding a new balance between openness and protection. Brussels, 2019

22 European Commission, Mergers: Commission clears partnership between EDF and CGN. Brussels Daily News 11/03/2016 available at: https://europa.eu/rapid/press-release_MEX-16762_en.htm Last accessed on 01/10/2010.
} 
internal market and the European Economic Area Agreement" on condition of divestiture of significant parts of its European pesticide and plant growth regulator business. ${ }^{23}$ On the other hand, number of other recent mergers involving Chinese companies in 2018-2019, where Commission established its jurisdiction, were declared compatible through a simplified procedure, i.e. quickly, without any remedies, and with the public version of the decision not longer than four brief paragraphs. ${ }^{24}$

Even though one could argue, that considering the aggregate turnover of all Chinese SOEs for the purpose of any merger affecting EU markets would lead not only to a positive conclusion concerning the jurisdiction issue but also regarding the potential of merged companies to impede competition, the opposite is true, at least for the time being. The explanation is obvious: under the EUMR the Commission is obliged to maintain and develop effective competition within the EU/EEA market (taking into account also the potential competition from undertakings located within or out of the EU/EEA) so that the competition in the EU/EEA market (or a substantial part of it) is not significantly impeded, namely by the creation or strengthening of a dominant position on that market. ${ }^{25}$ As we are witnessing the very first wave of Chinese acquisitions in Europe, quite naturally, the EU/EEA market shares of Chinese companies before the concentration were insignificant if not non-existent and only when the acquired company was already large enough in the EU/EEA markets (like aforementioned Syngenta) the case could raise some concerns regarding the economic and financial power of the larger entity. As only a "lasting damage to competition" (i.e. to consumer welfare and EU Single Market functioning) and not to other interest or values should be averted by the EUMR application ${ }^{26}$, there is no ground for the Commission to intervene against these first entries of Chinese SOEs into European business.

\footnotetext{
23 Case M.7962 -Chemchina/Syngenta decision of 05/04/2017 and also Mergers: Commission clears ChemChina acquisition of Syngenta, subject to conditions, European Commission Press Release IP/17/882, Brussels 05/04/2017.

24 See for instance: Case M.8903 - BHAP/Gestamp China/ Manufacturing JV/ Sales JV of 12/06/2018; Case M.9075 - Continental/CITIC/JHTD/JV of 29/10/2018; Case M.9150 - China Reinsurance Group Corporation /Chaucer of 17/12/2019; Case M.9243 - KRK/China Resources/Genesis Care of 14/02/2019; Case M.9258 - ANTA Sports Products/Fountaininvest China Capital Partners GP3/Amer Sports of 19/02/2019; CaseM.9262 -Macquaire/China Investment Corporation/ Allianz/Dalmore/INPP/Gas Distribution Business of National Grid of 10/05/2019.

25 See Art 2 of EU Regulation 139/2004 on the control of concentrations between undertakings (EUMR).

26 Data shows that ,the Commission has a good track record of applying EU Merger Regulation without having regards to political or other non-competition criteria“. See Fountoukakos, K. and Puech-Baron, C., op. cit. note 9, p. 8.
} 
Such a "lenient opening" may not last forever if we expect the Chinese economic expansion to continue and foresee future acquisitions by Chinese companies already established in Europe during the first wave of purchases. Then, referring to the conclusions made in the previous chapter, we may even witness a certain over-enforcement of competition law prohibitions as the aggregated market share of Chinese SOEs, their EU-based subsidiaries and branches, may become important on the affected relevant markets in the EU/EEA. Also the argument, that N. Petit calls "default assumption of a subjacent coordination scheme", may become of frequent use as with the increasing Chinese presence on European markets strategic accommodation between seemingly independent Chinese companies could not be ruled out due to influence of CCP over their management and foreign expansion. ${ }^{27}$ This would, of course, only apply to cases when such a well-established Chinese company takes over an independent EU-based undertaking and not necessarily to cases when companies under Chinese control would combine between themselves (as was already explained above). This is however a very uncertain prediction, whose probability may increase if current discussions about the EUMR reform lead to taking long-term risks into account when assessing the impact, notified of mergers.

\subsection{MULTIPLE PROHIBITIONS ON STRATEGIC AND SECURITY GROUNDS}

However, there is already existing tool to restrict at least those Chinese acquisitions that pose a non-competition threats to European interests. The EUMR itself allows in its Art 21(4) for the protection of legitimate interests other than those taken into consideration by the provisions of this Regulation, such as public security, plurality of media, prudential rules or any other public interest dear to Member States (provided it is communicated to the Commission in order to ascertain its non-protectionist nature). Member States can thus themselves, alongside of deciding on their own about mergers that fall below the "Community dimension" thresholds, prevent the concentrations that the Commission would consider inoffensive for competition on the affected EU/EEA markets. And the statistics show that only in 2018 seven acquisitions by Chinese companies were blocked by EU Member States - mainly on national security grounds ${ }^{28}$. On top of that, the new EU Regulation 2019/452 of 19 March 2019 establishing a framework for the screening of foreign direct investments

\footnotetext{
27 Petit, N. op. cit. note 9., p. 14-15.

28 de Corre, P. On China's Expanding Influence in Europe and Eurasia. Testimony before the House of Representatives Foreign Affairs Committee. May 9, 2019, published by Carnegie Endowment for International Peace.
} 
into the Union invites all Member States to introduce control mechanisms on the grounds of security and public order, and to ensure Union-wide coordination and cooperation on the screening of foreign direct investments likely to affect security or public order ${ }^{29}$.

It is therefore more likely that Chinese companies (SOEs and private ones alike) will be much more concerned by these Member States' powers and mechanisms of FDI control than by the European Commission's scrutiny under the EUMR. It is already expected (based on the nature of Chinese FDI in Europe in 2018) that as much as $92 \%$ of the value of Chinese FDI will be subjected to the new screening mechanisms of EU Member States. ${ }^{30}$ This means that many deals can be cancelled not because of their presumed impact on competition, but rather on the other public interests (security and public policy) especially when directed to the wide range of sensitive sectors. ${ }^{31}$ Needless to stress that, at least de iure, the application of the new Regulation should be without prejudice to the application of the EUMR, including of its aforementioned Art 21(4). ${ }^{32}$ The competition scrutiny thus should stay independent visa-vis the protection of other interests and the Commission will keep its unique position of guardian regarding the impact of concentrations with a "Community dimension" on competition in the EU/EEA markets. Instead of speculating about possible future effects of the very new FDI screening Regulation, it would be therefore more useful return to the EUMR and its capacity to cope with the challenges posed by Chinese SOEs.

\section{PENDING QUESTIONS, POSSIBLE ANSWERS}

The consequences of the fact that the European Commission would consider several or all Chinese SOEs as belonging to one single economic unit are not

\footnotetext{
29 See Recital 7 of EU Regulation 2019/452.

30 de Corre. P. op. cit. note 28.

31 The Regulation 2019/452 stresses in its Art 4 inter alia the following sectors: (a) critical infrastructure, whether physical or virtual, including energy, transport, water, health, communications, media, data processing or storage, aerospace, defence, electoral or financial infrastructure, and sensitive facilities, as well as land and real estate crucial for the use of such infrastructure; (b) critical technologies and dual use items as defined in point 1 of Article 2 of Council Regulation (EC) No 428/2009 (15), including artificial intelligence, robotics, semiconductors, cybersecurity, aerospace, defence, energy storage, quantum and nuclear technologies as well as nanotechnologies and biotechnologies; (c) supply of critical inputs, including energy or raw materials, as well as food security; (d) access to sensitive information, including personal data, or the ability to control such information; or (e) the freedom and pluralism of the media.
}

32 See in para 36 of EU Regulation 2019/452. 
exhausted by the doctrinal and legal impossibility to review mergers between them or between their subsidiaries and branches in the EU. For the same reason, consisting in the existence of one single economic unit, it is also prevented to apply Art 101 TFEU, prohibiting cartel agreements, to mutual relationships between them. Two or more entities subjected to the same strategic control are not supposed to compete one with another as if they were really independent undertakings. The EU competition law application may thus be blocked in more than one area if the dependence of Chinese SOEs on Chinese authorities made them parts of one and that same undertaking. Only the Art 102, prohibiting the abuse of dominant position (but not the dominant position itself) would remain at hand when the EU Competition law would spot a danger coming from Chinese SOEs behavior, however, not from their dominance as such, on the EU/EEA market.

One may say that the EU competition law finds itself caught between Scylla and Charybdis. If it maintains its current definition of undertaking / single economic unit and its current approach to the assessment of Chinese SOEs dependence on Chinese State authorities, it would remain powerless face to face with an increasing market dominance of entities that thanks to their belonging to the same economic unit can combine between themselves without any competition law backstops. If it decides not to wait for this really "worst case scenario" to materialize, it would have to abandon either its current definition of undertaking / single economic unit, or to apply it differently to entities coming from State controlled non-market societies, facing thus risk of being accused of double standards and of protectionism hidden behind complicated legal constructs.

\subsection{TO SPLIT THE CONCEPT OF UNDERTAKING FOR EX-ANTE AND EX-POST ASSESSMENTS}

As the first possibility, consisting in passive assistance to destruction of Single Market competitive environment is out of question - at least for being in direct contradiction with the EU Treaties goals and values - we have to consider the second option. How the concept of undertaking / single economic unit can be re-interpreted in order to handle the substantive differences represented by Chinese SOEs? The key argument here would be that EU competition rules should not be deprived of their practical effect (meaning that they must maintain the capacity to really protect the competitive structure of the EU/EEA markets). It is supported by the above cited provisions of the Treaties as well as by the case law of the EU Court of Justice (CJEU). This Court even admits, that in order to maintain the effet utile of competition rules, the concept of an economic unit in one area (of State aid in the case C-480/09 P from 2010) 
"can differ from that applicable in other areas of competition law" i.e. in the field of restrictive practices and concentrations. ${ }^{33}$ It has been thus laid down that the interpretation of single economic unit concept does not need to be always uniform and identical, if the insistence on its unity and sameness would compromise the achievement of open and undistorted competition on the EU Single Market.

Although there is so far no CJEU decision separating the meaning of single economic unit in the restrictive practices area from the one in concentrations, it is at least not excluded that for the sake of "not depriving the EU rules of competition of their practical effect", such a split may be recognized one day. Concentrations by nature and by procedure are closer to State aids than to restrictive practices. Both concentrations and State aids are controlled ex-ante, the plausible future has to be predicted in order to tell whether there is any danger for competition. Contrary to the restrictive practices that are investigated ex-post when the offense was committed and the evidence of past behavior has to be collected, in the areas of concentrations and State aids the Commission has to work with the most probable models and scenarios. Under them a mere possibility of a State authority to direct company behavior should be sufficient to conclude that the company concerned may not have the necessary independence of decision. On the other hand, when looking back, it should be possible to tell, without resorting to a mere possibility argument, whether the restrictive practice was really coordinated from one center or rather agreed between subsidiaries within their operational autonomy. This would allow applying Art 101 TFEU to (maybe) majority of cartel agreements and concerted practices between different Chinese SOEs and their EU-based daughter companies and branches. ${ }^{34}$

\subsection{TO DIFFERENTIATE PRIVATE UNDERTAKINGS FROM SOES IN EX-POST ASSESSMENTS}

The more demanding evidential requirements concerning the existence of single economic unit in case of cartel practices would not be without side effects.

\footnotetext{
33 CJEU Case C-480/09 P AceaElectrabel Produzione SpA v European Commission [2010], paras 62-67.

34 This solution was proposed a.o. by Petit, N. op. cit. note 9, p. 15: „In ex-ante merger review, more drastic legal doctrines that minimize the risk of non-notification may be required because it is impractical to unwind industry concentration ex-post. Moreover, in EU merger control law, it is indisputable that firms that are otherwise independent can be deemed to belong to a „group“ of firms for jurisdictional and substantive purposes, upon the showing of direct or indirect links between them."
} 
On one hand, more agreements between loosely linked companies may be caught by Art 101 TFEU which can hardly be welcomed by EU industrial groups. On the other hand, the "parental liability doctrine" that gives to the Commission the possibility to keep parent companies responsible jointly with their subsidiaries - direct participants to anti-competitive practices, may become more difficult to apply. Therefore, it is more than likely that neither the regulator not the regulated subjects would be satisfied with that solution. As the way out it could be envisaged to combine this proposal with another one. J. Briguet in his article from $2018^{35}$ argued that if the principle of competitive neutrality is to be maintained, public ownership should not have the advantage of being de facto excluded from major part of competition scrutiny - due to the possibility that many or all State-controlled companies may belong to the same economic unit - while typical private-owned companies (or their groups as single economic units) would always be exposed to competition law checks and sanctions for their potentially restrictive practices.

The proposed differentiation could mean a mere pushing forward of an already existing difference between tests applied by the Commission. In case of private corporate groups, the Commission applies a rebuttable presumption that $100 \%$ (or overwhelming majority) ownership implicates the exercise of actual influence. Then it is up to the companies concerned to refute such a presumption $^{36}$. In case of SOEs, as was demonstrated above on the example of Commission's reasoning in the EDF/CGN/NNB case, an analysis of channels of potential influence on decision making is carried out by the Commission itself in order to conclude whether dependence in decision making is possible. To split the two situations even more the question posed to SOEs would have to rephrased: Whether a State in its capacity of an owner entitled to take strategic decisions (which is enough to involve it in an assessment carried out ex-ante) really participated in the restructuration operation or the cartel scheme under an ex-post investigation? In a bit more radical version this approach would mean that relations as well as concentrations between companies owned by the same State will be refused the quasi-automatic advantage of being qualified as internal developments inside the same economic unit.

Several other arguments could be raised in support of such solutions. Private undertakings in a parental position always share the main intention of their subsidiaries as the profit-searching goal belongs to the very definition of en-

\footnotetext{
35 Briguet, J. op. cit. note 9, p. 855-856.

36 For a thorough explanation of the „single economic entity“ doctrine and the „test of control" see in Whish, R., Bailey, D., Competition Law, 9th edition. Oxford University Press 2018, pp. 93-97.
} 
trepreneurship ${ }^{37}$. Contrary to this community of interest typical for business structures and their activities, States are always multi-dimensional regarding the interests they pursue and may go after political, social, educational, cultural, as well as economic goals. It would be therefore justified to ask whether in a case at hand the State had not only the possibility but also a vested interest to take part in business decision making. From a more politicized point of view one may ask: why should be the State-owned economic units left free to dominate EU/EEA markets by internal coordination and combination between their parts without any hindrance from the competition law side? Moreover, if such an advantage was given to State-owned economic units, would not it push for a creeping re-nationalization in certain industries in order to shelter them against competition scrutiny and build unchecked the "global industrial champions"?

The shift in the EU competition law approach towards SOEs should thus combine the two aforementioned proposals: the definition of undertaking would require a different test in case of restrictive practices and internal reorganizations between SOEs belonging to the same State. The necessity to maintain practical effect of competition rules, i.e. the existence of open and undistorted competition and the unacceptability of allowing de facto evasion of SOEs from competition scrutiny should be as arguments strong enough as they reflect core values of EU competition law, even of the EU law as such ${ }^{38}$. They are therefore both equally valid as grounds for changes in competition law interpretation and practice.

The proposed solution presents double benefit, first of being consistent with the EU primary (competition) law, i.e. these "constitutional" values and provisions that are used by the CJEU to shape the interpretation of the EU secondary law (like the EUMR), and second of sparing the EU from the need to invent specific rules for companies coming from countries with different cultural backgrounds and political systems. It is quite evident that introducing extra rules for Chinese (or Russian) SOEs would only complicate business and trade relations with these countries whose markets are so attractive for EU companies and it would also be difficult to demand from them reciprocity in opening to foreign companies and in guaranteeing them the non-discriminatory treatment. That is why the proposed solution consisting in re-interpretation of the concept of

\footnotetext{
37 „The capacity and willingness to develop, organize and manage a business venture along with any of its risks in order to make a profit." Read more: http://www.businessdictionary.com/ definition/entrepreneurship.html Last accessed on 01/10/2010.

38 See for instance Art 119 TFEU that stresses twice „the principle of an open market economy with free competition" but also several other provisions pointing to the same direction (Art 3(3) SEU, Protocol no 27...).
} 
undertaking / single economic unit by the Commission and ultimately by the CJEU seems to be the best one.

\section{CONCLUSION}

Different corporate paradigm represented by Chinese SOEs definitely poses a challenge to EU competition law concepts and application practice, if the EU wants to maintain competitive structure of EU/EEA markets and at the same time its traditional unified and neutral approach to subjects regulated by competition law - undertakings. Although the current Commission's scrutiny of cases involving Chinese SOEs is rather piecemeal and we still miss any trendsetting precedent, if it is - at least in theory - continued and settled, it could lead to abandon of any competition scrutiny of "internal" mergers, agreements or concerted practices, between SOEs under control of the same State authority (or the CCP in the case of China). This could bring about an excessive concentration of economic power in many sectors of European economy, i.e. to produce an outcome that would be in open contradiction with fundamental values of the EU competition law and the EU Treaties in general. It suffices to remind that already the original ordo-liberal credo behind European competition rules stressed the fundamental incompatibility of the concentrated economic power not with efficiency but with freedom and social justice, the cherished European values. ${ }^{39}$

The present analysis dealt with two ways of a solution. The political one was covered only briefly as it consists in the control of foreign FDIs or concentrations involving foreign SOEs at the level of EU Member States under the angle of their strategic national and public interests. This way is different from pure competition law scrutiny but could alleviate the threat that SOEs supported by any non-EU great power become capable of influencing national policies and national security strategies in the EU. The main attention here was however paid to the existing EU competition law instruments and concepts and their capacity to cope with the Chinese SOEs expansion to European markets so that the open and undistorted competition is maintained on them.

There is almost a unanimous apprehension of authors working on this issue that the current EU concept of undertaking / single economic unit and the

\footnotetext{
39 Already in the early days of European integration, one of the spiritual fathers of German ortho-liberalism, Franz Böhm (1895-1977), warned that the concentrated economic power can be economically efficient, but if we are concerned about freedom and social justice, then we must keep the competition system free of concentrated economic power. See in Crane, D. A., Hovenkamp, H. (Eds.) The Making of Competition Policy: Legal and Economic Sources. Oxford University Press 2013, pp. 264-266.
} 
standards of its application do not fit into the reality of State-controlled economies and their State-supported and directed companies. The core of the problem consists in the fact that under the existing EU competition law approach the possibility of dependence in strategic decision-making deprives the entity of the undertaking status and makes it a part of an economic unit. And if the central controller-decision maker is the State (or the Party behind and above that State) then all SOEs should belong to the same economic unit. This makes them "big enough" to be controlled by the European Commission when they want to acquire any business in Europe but also make their competition law scrutiny impossible if they just combine between themselves (including subsidiaries and branches under their control). Commission thus may have jurisdiction to assess many or even all entries of Chinese SOES to EU/EEA markets but then would not have power to intervene against agreements and mergers between them.

To solve that puzzle the EU competition law, it means the Commission and the CJEU, should, opt for different interpretation of the concept of undertaking / single economic unit for the purposes of SOEs ex-ante merger scrutiny on one hand, and their internal practices' ex-post investigation and sanctioning on the other. This would require assessing differently the existence of undertaking / of single economic unit in cases of private-owned and State-owned companies, namely by introducing the necessity to prove the vested interest of the State behind the combination involving SOEs belonging to its owner portfolio in order to conclude that the combination concerned was an internal affair of a single economic unit. Thanks to that the State-ownership would not enjoy the partial immunity from competition law scrutiny and the competition law would not lose its effectiveness in protecting open and undistorted competition against excesses of concentrated market power.

\section{LITERATURE}

1. Briguet, J., The State 's Invisible Hand: Chines SOEs Facing EU Antitrust Law. Journal of World Trade, 52 No. 5/2018.

2. Crane, D. A., Hovenkamp, H. (Eds.) The Making of Competition Policy: Legal and Economic Sources. Oxford University Press 2013

3. de Corre, P. On China's Expanding Influence in Europe and Eurasia. Testimony before the House of Representatives Foreign Affairs Committee. May 9, 2019, published by Carnegie Endowment for International Peace.

4. De Kok, J., Chinese SOEs under EU Competition Law. World Competition 40, No. 4/2017. 
5. Devonshire-Ellis, C., While the EU Frets about Chinese Investment in Infrastructure, the US Quietly Rearms it. Silk Road Briefing, March 14, 2019, available from: https://www.silkroadbriefing.com/news/2019/03/14/eu-frets-chinese-investment-infrastructure-united-states-quietly-rearms/

6. Fountoukakos, K., Puech-Baron, C. China/EU: The gradual evolution of the EU Commission's merger control decisional practice towards SOEs amidst an increasingly protectionist world. Concurrences - Revue des droits de la concurrence. International. n. 4/2017.

7. García-Herrero, A., Jianwei X., How to handle state-owned enterprises in EU-China investment talks. Bruegel Policy Contribution Issue n. 18, June 2017. -DOI: https://doi.org/10.2139/ssrn.3160514

8. James, T. A., Morse, H. M., Regulatory Hurdles facing Mergers with Chinese State-Owned Enterprises in the United States and the European Union. China Antitrust Journal, vol. 1 Issue 1, Summer 2017

9. Lauer, S. European companies can't compete against global giants. The Guardian, May 17, 2019.

10. O’Connor, S., SOE Megamergers Signal New Direction in China's Economic Policy. US-China Economic and Security Review Commission, Staff Research Report, May 24, 2019.

11. Pelkmans, J., „China's Socialist Market Economy“: A systemic Trade Issue. Intereconomics n. 2018/5 ZBW-Leibniz Information Centre for Economics.

-DOI: https://doi.org/10.1007/s10272-018-0764-1

12. Petit, N., Chinese State Capitalism and Western Antirust Policy. www.ssrn.com/ abstract'2798162 21/06/2016.

-DOI: https://doi.org/10.2139/ssrn.2798162

13. Ploquin, J.-C., Chine, comment les Européens veulent en finir avec le jeu de dupes. La Croix, 26 Mars 2019.

14. Pucci, J. ChemChina-Sinochem: The New Mega-Company. Agri Business Global, March 19, 2019, available at: https:/www.agribusinessglobal.com/markets/ asia/chemchina-sinochem-the-new-mega-company/

15. Svetlicinii, A., The Acquisition of the Chinese State-Owned Enterprises under the EU Merger Control Regime: Time for Reflection? Revue Lamy de la concurrence, N. 67 Décembre 2017;

16. Svetlicinii, A., The Acquisition of the Chinese State-Owned Enterprises under the National Merger Control of the EU Member States: Searching for a Coherent Approach. Market and Competition Law Review, Vol. II, No. 1. April 2018.

-DOI: https://doi.org/10.7559/mclawreview.2018.334

17. Toplensky, R., Brunsden, J., EU competition chief urges higher defences against China threat. The Financial Times, January 16, 2019. 
18. Toplensky, R., Brunsden, J., France calls for biggest shake-up of EU merger rules in 30 years. The Financial Times, February 12, 2019.

19. Whish, R., Bailey, D., Competition Law, 9th edition. Oxford University Press 2018

\section{DOCUMENTS AND REPORTS}

1. European Commission, Consolidated Jurisdictional Notice under Council Regulation 139/2004 on the control of concentrations between undertakings (2008/C 95/01).

2. European Commission, Staff Working Document on Significant Distortions in the Economy of The People's Republic of China for the Purposes of Trade Defence Investigations. Brussels, 20.12.2017 SWD(2017) 483 final/2.

3. European Political Strategy Center (the European Commission in-house think tank): EU Industrial Policy after Siemens-Alstom. Finding a new balance between openness and protection. Brussels, 2019.

4. A Franco-German Manifesto for a European industrial policy fit for the 21st Century. Feb 19, 2019 https://www.bmwi.de/Redaktion/DE/Downloads/F/franco-german-manifesto-for-a-european-industrial-policy.pdf\%3F__blob\%3DpublicationFile $\% 26 v \% 3 \mathrm{D} 2$

5. Modernising EU Competition Policy, a manifesto issued by Bundesministerium fur Wirtschaft und Energie (GER), Ministere de l'économie et finance (FRA), Ministerstwo Przedsiebiordzosci i Technologii (POL), July 4, 201, available at : https://www.bmwi.de/Redaktion/DE/Downloads/M-O/modernising-eu-competition-policy.pdf?__blob=publicationFile \&v=4

\section{OTHERS}

1. European Commission, Mergers: Commission clears partnership between EDF and CGN. Brussels Daily News 11/03/2016 available at: https://europa.eu/rapid/ press-release_MEX-16-762_en.htm

2. European Commission, Press release Database, Mergers: Commission prohibits Siemens' proposed acquisition of Alstom. Brussels, 6 February 2019 https:/europa.eu/rapid/press-release_IP-19-881_en.htm 
